\title{
The Fashion Design Curriculum: Implementing the Learning Freedom and COVID-19 Pandemic Era
}

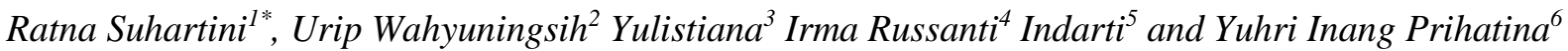

\author{
${ }^{123456}$ Department of Home Economic, Universitas Negeri Surabaya, Surabaya, Indonesia \\ *Corresponding author ratnasuhartini@unesa..ac.id
}

\begin{abstract}
This study aims to describe the implementation of the D4 Fashion Design curriculum during the COVID-19 pandemic. Curriculum 2018 in semester five, curriculum 2019 in semester 3, curriculum 2020 in semester 1. This type of research is descriptive qualitative. Data was collected through focus group discussions between lecturers, industry, alumni, and stakeholders. Data was also obtained from student learning results in odd semesters, interviews with partner stakeholders. The results show that learning for semester 1 students is still a concept course, learning is carried out online, teachers are a team of lecturers and industry partners. The learning output is a research report. Third-semester student learning is carried out in class and in the industry in the form of a survey. Lecturers are a team of lecturers with industry partners according to the expected course competencies. Learning output produces products. 5th-semester learning is carried out in collaboration with all courses. Lecturers are lecturers and industry partners. The output of learning about fashion design products according to personal themes. Types of evaluation are tests, portfolios, assignment reports, product assessments.
\end{abstract}

\section{Keywords: Fashion Design Diploma 4 Curriculum, Learning Freedom, Implementing in the COVID-19 Pandemic Era}

\section{INTRODUCTION}

The COVID-19 pandemic has the potential to reduce student learning competencies. Students who are supposed to study in a laboratory workshop, a study in industry, survey several fashion industries, and carry out practical work activities in the industry for 6 months in the industry, can no longer be done. Learning is carried out online at each home according to the lecture schedule. Attendance is done when students are present during the learning process and collect assignments. Learning is done through technology, virtual learning, zoom, google form, and what's app. Lecturers teach the material in the form of lectures and provide modules. The assignment is given at the end of the lesson. The task form is an individual task. Lecturers monitor student activities via WhatsApp and the like and provide guidance to students if there are difficulties in the learning process. The difficulty experienced by lecturers and students is the unpreparedness for distance learning. The main obstacle is that the network is not the same for each student. So that students are left behind in the teaching and learning process. The students must learn directly from the lecturer. This requires more time for the lecturer to complete the learning. Likewise, with practical courses, conducted online. Average practice results do not reach the maximum. Some weaknesses were obtained, the practical products were not as planned, because they were constrained by tools and materials that were difficult to obtain by students. During a pandemic, large-scale social restrictions are held. No one is allowed outside the house. The shops were not 
operating. Online shopping is difficult to get the desired ingredients.

The practice of fieldwork was interrupted in the middle of implementing the practice. The university replaced the online learning system, the parents of students did not allow their children to do activities outside the home, some industries were not willing to accept interns. The practice of fieldwork is transferred to making online industry surveys, then. From the survey results, articles were made. Articles were assessed by 2 reviewers from the lecturers. In the curriculum, the fieldwork practice course is carried out for 6 months, students make products with industrial characters, from these products are reported in the form of a written report. The next activity was a seminar on the results of industrial practice reports. Industrial practice seminar.

The transmission of COVID-19 is growing rapidly. Policymakers need guidance on how the general public to combat the COVID-19 pandemic. Reducing the spread of disease requires two things: first, limit contact with infected individuals through physical distance and other measures. The Covid-19 pandemic has caused social fear, resulting in social distance, schools, campuses, education, and training have stopped, placement of graduates has stopped, business centers, tourism has been closed, business investment has stopped, pressure on the public health system, disrupted government policies, resulting in a policy crisis (WHO: March 11, 2020).

Learning before the COVID 19 pandemic, students learn by taking 20-22 semester credit units. Each semester there are 3-4 practical courses that are required to produce products. During the COVID pandemic, learning continues according to schedule. Online learning is carried out using Vilearning, social networking, What'app, google zoom. Research on the obstacles to learning and teaching online at home due to the COVID-19 pandemic situation. The challenges and obstacles that students experience are limited communication and socialization among students, timeconsuming parents to help children learn, lack of technology skills, and higher internet bills. Constraints experienced are limitations in the choice of teaching methods, inadequate coverage of curriculum content, lack of technological skills, and lack of learning resources [1]. As a result of the pandemic, all schools, colleges, and universities were declared closed. This disrupts the entire education system. Policymakers face many obstacles in making policies related to the education system. Teaching takes place from offline to online. Due to this transformation in teaching methodology, students, teachers, and parents face many problems [2]. COVID-19 has had a negative impact on education and teaching, decreased access to education and research facilities, lost the jobs of many educators and students who rely on technology to ensure online learning. However, online education is hindered by poor infrastructure including, network problems, electricity. and poor digital skills [3]. Various obstacles are experienced by students and lecturers, so they are required to plan, implement, and evaluate learning in the fashion design expertise program. Studies on teachers' awareness of the COVID-19 pandemic and their opinion on the readiness of individual schools, as well as their responses to the challenges of delivering distance learning education in the Philippines. The results showed that teachers are very aware of the existence and consequences of the COVID-19 pandemic. length of teaching experience and specialization correlate very closely with readiness to take distance learning education [4].

Along with the COVID-19 pandemic, the government contains the concept of free learning. Freedom to study in higher education means that students do not only study on campus, but can study in a workplace environment, industrial environment, community, and village environment. This opportunity is open to all students for one semester studying outside of their study program. Students also have the right to two semesters outside the campus, namely crossregional student exchanges. In designing learning during the COVID-19 pandemic, it can collaborate with independent learning.

\section{LITERATUR REVIEW}

\subsection{Adjustment of the D4 Fashion Design Curriculum during the COVID-19 Pandemic}

Decree of the Minister of Education and Culture of the Republic of Indonesia Number 719 / P / 2020 concerning guidelines for implementing the Curriculum in the Education Unit in the Special Commission, the curriculum provides flexibility for universities to choose a curriculum that suits student needs. Virtually adjusting learning policies during the Covid-19 pandemic. In special conditions in learning there are 3 curriculum options, namely 1) still referring to the curriculum, 2) using the emergency curriculum, simplifying the curriculum independently. The emergency curriculum prepared is a simplification of the existing curriculum. This can be done by reducing course material, lecture materials can focus on essential material. Thus, the emergency curriculum will provide flexibility. The target of achieving the current curriculum is a meaningful process and does not have a negative impact. The Director-General of Vocational Education, Ministry of Education and Culture, the application of a learning percentage of $60 \%$ practice and $40 \%$ theory must change the practical field learning strategy into a simulation. In addition, courses that require real 
practice are moved to the final semester during a pandemic. Practical hours during the pandemic were replaced with theory-based courses, making them easier to apply with distance learning.

Course material analysis is the activity of selecting essential material from the entire course material which is the minimum competency that must be achieved. The essential material includes the key concepts of competence, main themes and basic values which have characteristics, including: 1) Universal, the concept has a high level of generalization, 2) Adaptive, gives students the ability to adapt to changes and developments in knowledge and technology, 3) Transferable, the concepts contained in the material can be used for problemsolving in various ways, 4) Applicative, allowing it to be widely applied in various fields of science and technology, 5) Meaningful, meaningful and useful to know. The material analysis procedure is as follows: 1) identifying aspects that exist in the course, 2) Identifying the types of course material, 3) Choosing the type of material according to competencies 4) Orienting to student needs, 5) Orienting student development, 6) The material must be consistent.

Course scheduling refers to scheduling optimization. Models can minimize costs. Has two conditions, namely the cost of placing courses in a period in one day and in one week. Model parameters are data about courses, participants, teachers, days, time periods, and classrooms. [5]. The lecture scheduling is more complex because the length of time for each course is different[6]. Scheduling lectures according to teacher needs such as lecture time according to the teacher's time, lectures using sewing tools are used in rooms that have sewing facilities. Some courses are scheduled for more than one period each week, the participants are over capacity, the room is not allocated to that room, each course must be allocated exactly in one room at a time, there are courses that cannot be held at a certain time period because the lecture participants are prioritized following other courses, some courses cannot be scheduled sequentially, some entry-level courses must be scheduled at a specific time. This problem is also modeled in the form of ILP and solved by the branch and bound method. [7].

\subsection{Freedom of Learning}

Freedom to learn is freedom of thought. The purpose of independent learning is so that teachers, students, and parents can have a happy atmosphere, free from various pressures. Freedom to study in tertiary institutions requires giving students the right to volunteer, Students may take or not, 1) Can take 2 semesters of credits outside of college (equivalent to 40 credits). 2) Can take credits in different study programs at the same PT for 1 semester (equivalent to 20 credits). Thus, the credits that must be taken in the original study program are 5 semesters of the total semester taught. Changes in the definition of credits are 10 Each credit is defined as hours of activity, not teaching hours, 2) The definition of activities is learning in class, practical work (apprenticeship), student exchanges, projects in villages, entrepreneurship, research, independent studies, and teaching activities in remote areas. All activities must be guided by a lecturer determined by the College. 3) The list of activities in the 3 semesters taken by students can be selected from a) programs determined by the government $b$ ) programs approved by the rector.

Table 1 Independent Learning activity program

\begin{tabular}{|l|l|l|}
\hline \multicolumn{1}{|c|}{ Activities } & \multicolumn{1}{|c|}{ Explanation } & Note \\
\hline $\begin{array}{c}\text { Internships } \\
\text { practical work }\end{array}$ & $\begin{array}{l}\text { Apprenticeship activities in a company, } \\
\text { non-profit foundation, multilateral } \\
\text { organization, government agency, or } \\
\text { startup (startup). }\end{array}$ & $\begin{array}{l}\text { Must be guided by a lecturer / } \\
\text { instructor }\end{array}$ \\
\hline Village Project & $\begin{array}{l}\text { Social projects to assist communities in } \\
\text { rural areas, or in remote areas in } \\
\text { developing the economy, people, } \\
\text { infrastructure. }\end{array}$ & $\begin{array}{l}\text { Can be done together with the } \\
\text { village apparatus (the village } \\
\text { headher village organizations } \\
\text { other or }\end{array}$ \\
\hline Teaching in schools & $\begin{array}{l}\text { Teaching activities in elementary school } \\
\text { (SD), junior high school (SMP), senior } \\
\text { high school (SMA) for several months. } \\
\text { Schools can be in urban or remote } \\
\text { locations }\end{array}$ & $\begin{array}{l}\text { The program will be facilitated by } \\
\text { the Ministry of Education and } \\
\text { Culture }\end{array}$ \\
\hline
\end{tabular}




\begin{tabular}{|l|l|l|}
\hline Student exchange & $\begin{array}{l}\text { Classes or semesters at foreign or domestic } \\
\text { universities based on cooperation } \\
\text { agreements that have been held by the } \\
\text { government }\end{array}$ & $\begin{array}{l}\text { The value and credits taken at } \\
\text { foreign universities will be } \\
\text { equalized by each university }\end{array}$ \\
\hline Research & $\begin{array}{l}\text { Academic research activities, both foreign } \\
\text { and social and humanities, carried out } \\
\text { under the supervision of lecturers and } \\
\text { researchers }\end{array}$ & $\begin{array}{l}\text { It can be done for research } \\
\text { institutes such as LIPI / BRIN }\end{array}$ \\
\hline Entrepreneurial activities & $\begin{array}{l}\text { Students develop entrepreneurial activities } \\
\text { independently as evidenced by an } \\
\text { explanation/proposal of entrepreneurial } \\
\text { activities and proof of consumer } \\
\text { transactions or employee salary slips }\end{array}$ & $\begin{array}{l}\text { Must be guided by } \\
\text { lecturer/instructor }\end{array}$ \\
\hline $\begin{array}{l}\text { Independent study } \\
\text { project }\end{array}$ & $\begin{array}{l}\text { Students can develop a project based on a } \\
\text { special social topic and can be worked on } \\
\text { together with other students }\end{array}$ & $\begin{array}{l}\text { Must be guided by a lecturer / } \\
\text { instructor }\end{array}$ \\
\hline Humanitarian project & $\begin{array}{l}\text { Social activities for a Foundation, a project } \\
\text { based on a special social topic and can be } \\
\text { done together with other students. }\end{array}$ & $\begin{array}{l}\text { Examples of formal organizations } \\
\text { that can be approved by the } \\
\text { Chancellor. Indonesian } \\
\text { Cross, Mercy Corps, and others }\end{array}$ \\
\hline
\end{tabular}

Ministry of Education and Culture, 2020

\subsection{Distance Learning}

Technology is a key component of education. Facilitating technology facilitates distance learning. Education stakeholders, students, teachers, and even parents are faced with the sign of transition to online education. Various training and webinars are organized to meet the diverse needs of students. The concept of online education is a key component of 21st-century education. Technology facilitates virtual distance learning, mixed learning, distribution learning. It is a development of learning methods, where teachers act as facilitators, mentors, and motivators to inspire, participate, and learn [9]. Efforts to normalize post-pandemic e-Learning pedagogy opens a discourse on how the sector can be emancipatory for all students. Emergency e-Learning normalization means normalization in the form of education that perpetuates structural inequalities of class, race, and support [10] (Michael P. A. Murphy (2020).

Web-based learning technologies have greatly expanded the open, flexible, and distance education environment. In line with this growth, efforts need to be made to meet the diverse needs of learners and increase our capacity for diversity, in all its forms. While it may be tempting to think that online environments are inherently more accommodating of diversity, [11] that the factors that make students successful in using instructional technologies are often associated with socioeconomic privileges. In addition, the recent COVID-19 pandemic has taught us that a smooth transition to online and distance learning is for those with the resources, while most students have experienced considerable stress and grief simply finding a place in the world. where they can enter the Internet or even comfortable. a way to communicate with their instructor. Most of what schools do cannot even be called online or distance learning, with terms like emergency or lighter distance learning being applied instead [12].

\subsection{Practical Skill Learning}

Learning in tertiary institutions focuses on practical skills, has the potential to be held in a short time, can be used quickly, and uses blended modules, improves skills for work, applies Work-Based Learning (offline at work or online) which is possible with Covid-19 standards. Learning to work according to workplace culture and workplace norms often require interpretation and adaptation by individual students. [13]. The main advantage of Workplace-Based Learning (WPBL) is gaining experience in the professional field and starting to work live with the knowledge of the market, organizational structure, and entrepreneur expectations [14]. The Work Integrated Learning (WIL) program has a positive effect on the development of students' personal and pre-professional identities, creates awareness of the challenges posed by the profession, focuses on effective practice of developing personalities and motivates students to learn independently and think 
critically which can bridge the gap between theory and practice [15].

Experiential learning is not just an integration of theory and practice but can (and should be) transformative, creating new knowledge, skills, and attitudes for students that both theory and practice alone can achieve. Practical learning can also be done with industry in the form of internships. The relationship between internships and academic programs is a significant predictor of student internship satisfaction and perceived value for their career development. ([16] . Practicing using virtual laboratories can develop life skills including personal skills, thinking skills, social skills, and vocational skills. The life skill learning process consists of several aspects: 1) planning: curriculum, facilities, 2) implementation including methods and techniques, Turo competency media, teaching materials or materials, time and schedule, 3) evaluation of learning outcomes [17] .

Assessment can be done in the workplace. Assessment is part of the teaching and learning cycle. The assessment aims to inform students and lecturers where knowledge gaps are and what academic improvements and interventions may be needed. This view is in line with the statement of [18] that "assessment is a systematic collection of information about student learning, use of time, knowledge, skills, and available resources, to inform decisions that affect student learning. Assessment is the core of the learning process that itself [19], requires student institutions in academic and professional development [20] with reference to WPBL, [21].

Some research on workplace assessment is a WPBL (workplace Based Learning) assessment which is as follows: 1) WPBL results vary depending on the placement environment 2) some tasks are collaborative, making individual performance difficult to assess 3) Assessment instruments need to measure learning achievement desired in a variety of workplace settings where the intensity and rigor of results may not prevail. [22] (Ferns and Zegwaard (2014). Portfolios as an effective assessment method are carried out in fashion design expertise programs because: (1) allow for task integration; (2) offer insight into how each assessment criterion is handled, and (3) describes "the entire learning process and reflects how, when and where different concepts, abilities and competencies have been acquired [22]. Experience-based learning portfolios are one of the most comprehensive methods for assessing WPBL (work-based learning), the feature that distinguishes them is the reflection component. [21] asserts that "Portfolio learning is not just a work of student material, but a deliberately designed collection of connected by carefully thought-out structured student reflections [21]. With portfolio assessment students and lecturers can reflect. Reflection requires understanding and analytical thought processes of events and activities, in order to gain a better understanding of improving future practice. [23], referring to Schön's two concepts of reflection, namely, "Reflection-on-action, the analytical process of thinking about the experience after it has occurred, and reflection-in-action, the thought at the moment that gives rise to the experiment.

\section{METHODOGY}

This type of research is descriptive qualitative. The research was carried out during the COVID-19 pandemic. The research object is the D4 fashion design curriculum. The data collection instruments used interviews and observations. The research procedure is 1) analyzing the ongoing curriculum, material analysis, practical analysis, and practicum. 2) Mapping lecture schedules, 3) Focus Group Discussion attended by all teaching lecturers, industry partners, and faculty leaders. The results of the discussion are recorded. The data analysis was done qualitatively, namely data reduction, data presentation, and conclusion drawing. Data reduction was carried out on the results of focus group discussions, general elections, simplification, then presented in lecturer discussions. Triangulation is carried out by checking the results of lecturers' discussions, the curriculum, applicable regulations, and the conditions of the Covid-19 pandemic.

\section{DISCUSSION}

Next, plans for odd semester courses for 3 batches will be drawn, namely the D4 Fashion Design 2020, 2019, and 2018 expertise program. Schedule mapping is based on the principle of equity. Each lecturer receives balanced teaching credits. By paying attention to lecturer competence. Schedule mapping appears once a week. Schedule of theoretical courses according to study hours. However, practical courses have different hours, namely theoretical credits, structured credits, and independent credits.

The results of the focus group discussion show that there are several courses that can be conducted by team teaching with industry, there are several courses that can be independent, lecturers as teachers. A course that can be taught independently is a theory course. Some of the practical courses and theoretical courses can be seen below

Table 2. Subjects D4 Fashion Design 2020

\section{D4 Fashion Desion 2020}




\begin{tabular}{|c|c|c|c|c|}
\hline 1 & Civic & 2 & Theory & Team \\
\hline 2 & $\begin{array}{l}\text { Indonesian } \\
\text { Language }\end{array}$ & 2 & Theory & Team \\
\hline 3 & $\begin{array}{l}\text { Physical } \\
\text { Education and } \\
\text { Fitness }\end{array}$ & 2 & Theory & Team \\
\hline 4 & $\begin{array}{l}\text { Introduction to } \\
\text { the Fashion } \\
\text { Industry }\end{array}$ & 2 & Theory & $\begin{array}{l}\text { Lecturer } \\
\text { in the } \\
\text { field of } \\
\text { study }\end{array}$ \\
\hline 5 & Textile & 2 & $\begin{array}{l}\text { Theory \& } \\
\text { Practice }\end{array}$ & $\begin{array}{l}\text { Lecturer } \\
\text { in the } \\
\text { Field of } \\
\text { Study \& } \\
\text { Industry } \\
\text { Partners }\end{array}$ \\
\hline 6 & Basic Design & 2 & Theory & $\begin{array}{l}\text { Lecturer } \\
\text { in the } \\
\text { field of } \\
\text { study }\end{array}$ \\
\hline 7 & Model Image & 2 & $\begin{array}{l}\text { Theory \& } \\
\text { Practice }\end{array}$ & $\begin{array}{l}\text { Lecturer } \\
\text { in the } \\
\text { Field of } \\
\text { Study \& } \\
\text { Industry } \\
\text { Partners }\end{array}$ \\
\hline 8 & $\begin{array}{l}\text { Industrial } \\
\text { Machinery \& } \\
\text { Occupational } \\
\text { Health Safety }\end{array}$ & 3 & $\begin{array}{l}\text { Theory \& } \\
\text { Practice }\end{array}$ & $\begin{array}{l}\text { Lecturer } \\
\text { in the } \\
\text { field of } \\
\text { study }\end{array}$ \\
\hline 9 & $\begin{array}{l}\text { Clothing } \\
\text { Production I } \\
\text { (archetype, skirt } \\
\text { \& sackdress } \\
\text { prototype) }\end{array}$ & 3 & $\begin{array}{l}\text { Theory \& } \\
\text { Practice }\end{array}$ & $\begin{array}{l}\text { Lecturer } \\
\text { in the } \\
\text { field of } \\
\text { study }\end{array}$ \\
\hline & & 21 & & \\
\hline
\end{tabular}

The D4 Fashion Design 2020 Fashion design expertise program, has institutional courses, namely Pancasila, Indonesian, and Sports as characters from University courses.

Table 3. Subjects D4 Fashion Design 2019

\begin{tabular}{|c|c|c|c|c|}
\hline 1 & $\begin{array}{l}\text { Physical } \\
\text { Education and } \\
\text { Fitness }\end{array}$ & 2 & Theory & Team \\
\hline 2 & $\begin{array}{l}\text { Excellent } \\
\text { Communication } \\
\text { and Service }\end{array}$ & 2 & Theory & $\begin{array}{l}\text { Lecturer } \\
\text { in the } \\
\text { field of } \\
\text { study }\end{array}$ \\
\hline 3 & $\begin{array}{l}\text { History of } \\
\text { Clothing }\end{array}$ & 2 & Theory & $\begin{array}{l}\text { Lecturer } \\
\text { in the } \\
\text { field of } \\
\text { study }\end{array}$ \\
\hline 4 & $\begin{array}{l}\text { Fashion Design } \\
\text { Concepts }\end{array}$ & 3 & $\begin{array}{l}\text { Theory } \\
\& \\
\text { Practice }\end{array}$ & $\begin{array}{l}\text { Lecturer } \\
\text { in the } \\
\text { Field of } \\
\text { Study \& } \\
\text { Industry } \\
\text { Partners }\end{array}$ \\
\hline 5 & $\begin{array}{l}\text { Men's Fashion } \\
\text { Design }\end{array}$ & 3 & $\begin{array}{l}\text { Theory } \\
\& \\
\text { Practice }\end{array}$ & $\begin{array}{l}\text { Lecturer } \\
\text { in the } \\
\text { Field of } \\
\text { Study \& } \\
\text { Industry } \\
\text { Partners }\end{array}$ \\
\hline 6 & Draping II & 3 & $\begin{array}{l}\text { Theory } \\
\& \\
\text { Practice }\end{array}$ & $\begin{array}{l}\text { Lecturer } \\
\text { in the } \\
\text { Field of } \\
\text { Study \& } \\
\text { Industry } \\
\text { Partners }\end{array}$ \\
\hline 7 & $\begin{array}{l}\text { Clothing } \\
\text { Production III } \\
\text { (traditional dress, } \\
\text { blazer) }\end{array}$ & 3 & $\begin{array}{l}\text { Theory } \\
\& \\
\text { Practice }\end{array}$ & $\begin{array}{l}\text { Lecturer } \\
\text { in the } \\
\text { field of } \\
\text { study }\end{array}$ \\
\hline 8 & Textile Crafts & 3 & $\begin{array}{l}\text { Theory } \\
\& \\
\text { Practice }\end{array}$ & $\begin{array}{l}\text { Lecturer } \\
\text { in the } \\
\text { field of } \\
\text { study }\end{array}$ \\
\hline & & 21 & & \\
\hline
\end{tabular}

Table 4. Subjects D4 Fashion Design 2018

\begin{tabular}{|c|l|c|c|l|}
\hline \multicolumn{5}{|c|}{ D4 Fashion Desion 2018} \\
\hline 1 & Design Mode IV & 3 & & $\begin{array}{l}\text { Lecturer in } \\
\text { the field of } \\
\text { study }\end{array}$ \\
\hline
\end{tabular}




\begin{tabular}{|c|l|c|l|l|}
\hline 2 & $\begin{array}{l}\text { Clothing Production } \\
\text { V }\end{array}$ & 4 & & $\begin{array}{l}\text { Lecturer in } \\
\text { the field of } \\
\text { study }\end{array}$ \\
\hline 3 & $\begin{array}{l}\text { Fashion Branding \& } \\
\text { Digital Marketing }\end{array}$ & 3 & & $\begin{array}{l}\text { Lecturer in } \\
\text { the field of } \\
\text { study }\end{array}$ \\
\hline 4 & Entrepreneurship & 3 & & $\begin{array}{l}\text { Lecturer in } \\
\text { the field of } \\
\text { study }\end{array}$ \\
\hline 5 & Research Methods & 3 & & $\begin{array}{l}\text { Lecturer in } \\
\text { the field of } \\
\text { study }\end{array}$ \\
\hline 6 & Cash flow/accounting & 2 & & $\begin{array}{l}\text { Lecturer in } \\
\text { the field of } \\
\text { study }\end{array}$ \\
\hline & & $\mathbf{1 8}$ & & \\
\hline
\end{tabular}

The 5th-semester course for Fashion Design students is a collaboration of all the planned courses. The final product will be deployed virtually. The output of all learning in 5 is a Fashion Design Product in accordance with the planned theme design and will be held in the form of a fashion show. Below shows the relationship between courses. All courses lead to one goal, namely fashion products for fashion shows. Lectures are conducted in a Block system, starting with Design Mode IV. Fashion design 4 is designing designs according to

\section{CONCLUSION}

The implementation of the D4 Fashion design curriculum has not fully implemented the independent learning curriculum. Freedom to learn in the implementation of this course is to study in the industry online for one semester. Learning applies distance learning using virtual learning, WhatsApp, zoom meeting and google form. Learning applies to practical skills. Assessment includes participation, assignments, midterm, and final exams. Participation value is the value of student activity in the teaching and learning process, midterm, and final semester exams conducted online. Assessment of assignments in the form of papers, products, and portfolios.

\section{REFERENCES}

[1] Ratna Setyowati Putri, Agus Purwanto , Rudy Pramono, Masduki Asbari, Laksmi Mayesti the theme. The output of the design course is 2 designs to be used as clothing. The design comes complete with accessories. The clothing production course is producing clothing according to the designs that have been produced. The output is clothing. Fashion Branding and Digital marketing courses are planning brand and digital marketing of clothing products that have been produced in the Clothing Production V course. Cashflow/accounting teaches how to calculate the selling price of these clothes. In the entrepreneurship course, students prepare entrepreneurial plans with products that are produced from clothing production $\mathrm{V}$ and already have branding. The research method subject is compiling research according to the clothes produced. Research starts from the very beginning of the design process to the fashion show. The outputs of research courses are proposals and proposal seminars.

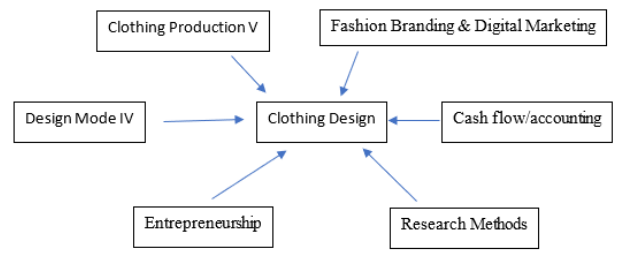

Learning assessment refers to the lecture manual. Assessment includes 4 components. Assessment is participation, assignment assessment, midterm examination assessment, and final semester assessment. Each assessment has a proportion. The participation value has a weight of $20 \%$, a $30 \%$ assignment score, $20 \%$ midterm exam scores, and $30 \%$ final semester test score

Wijayanti,. 2020 Impact of the COVID-19 Pandemic on Online Home Learning: An Explorative Study of Primary Schools in Indonesia. International Journal of Advanced Science and Technology. Vol. 29 No. 05 (2020): Vol. 29 No. 05 $\underline{(2020)}$

[2] Preeti Tarkar.2020. Impact Of Covid-19 Pandemic On Education System. International Journal of Advanced Science and Technology. Vol. 29 No. 9s (2020): Vol. 29 No. 9s (2020) Special Issue

[3] Edeh Michael Onyema1* Dr. Nwafor Chika Eucheria2 Dr. Faith Ayobamidele Obafemi 3 Shuvro Sen4 Fyneface Grace Atonye5 Dr. Aabha Sharma6 Alhuseen Omar Alsayed7. Impact of Coronavirus Pandemic on Education. 2020. Journal of Education and Practice. Vol.11, No.13, 2020. DOI: $10.7176 / J E P / 11-13-12$ 
[4] Aris Alea Lapada, Frosyl Fabrea Miguel, Dave Arthur Roldan Robledo, Zeba F Alam. 2020. Teachers' Covid-19 Awareness, Distance Learning Education Experiences and Perceptions towards Institutional Readiness and Challenges. International Journal of Learning, Teaching and Educational Research. Vol 19, No 6 (2020)

[5] Daskalaki S, Birbas T, \& Housos E. (2004). An integer programming formulation to a case study in University Timetabling. Eur J Operat Res, 153,117135 .

[6] Hinkin TR, \& Thompson GM. (2002). Schedul expert: Scheduling courses in Cornell University School of hotel administration. Interfaces, 32,45-57.

[7] Ng PH, \& Martin LM. (2002). Classroom scheduling problems: A discrete optimization approach. UMAP J, 23(1),57-66.

[8] Biggs, J. (2014). Constructive alignment in university teaching. HERDSA Review of Higher Education, 1, $5-22$

[9] Onyema, E.M., \& Deborah, E. C. (2019). Potentials of Mobile Technologies in Enhancing the Effectiveness of Inquiry-based learning. International Journal of Education (IJE), 2(1), 1-25. https://doi.org/10.5121/IJE.2019.1421

[10] Michael P. A. Murphy (2020) COVID-19 and emergency eLearning: Consequences of the securitization of higher education for post-pandemic pedagogy, Contemporary Security Policy, 41:3, 492505, DOI: $10.1080 / 13523260.2020 .1761749$ To link to this article: https://doi.org/10.1080/13523260.2020.1761749

[11] Barbour, M. K., \& Reeves, T. C. (2009). The reality of virtual schools: A review of the literature. Computers \& Education, 52(2), 402-416. https://doi.org/10.1016/j.compedu.2008.09.009

[12] Hodges, C., Moore, S., Lockee, B., Trust, T., \& Bond, A. (2020). The difference between emergency remote teaching and online learning. EDUCAUSE Review, 3. https://er.educause.edu/articles/2020/ 3/the-difference-between-emergency-remoteteaching-and-online-learning

[13] Sally Burford, Lesley Cooper, Faye Miller Stolen knowledge: Student knowing in workplace practice. 2019. International Journal of Work-Integrated Learning, 21(2), 163-176
[14] Du Pré, R. (2010). Universities of Technology in the context of the South African higher landscape. In Council on Higher Education, (Eds.), Universities of Technology-Deepening the Debate. (Kagisano No. 7, pp. 1-41). Pretoria, South Africa: Author

[15] Maryna Reyneke, Carolina Botha. 2019. The professional orientation of first year student teachers in a non-placement work-integrated learning program. International Journal of Work-Integrated Learning, 21(3), 303-316

[16]Matthew Hora1 Zi Chen, Emily Parrott, Pa Her. 2019. Problematizing college internships: Exploring issues with access, program design and developmental outcomes, International Journal of Work-Integrated Learning, 21(3), 235-252. Volume 20 (2019)

[17] Haryoko, S., \& Jaya, H. (2018). THE ROLE OF MULTIMEDIA TECHNOLOGY (LAVIRVIRTUAL LABORATORY) IN DEVELOPING LIFE SKILLS IN VOCATIONAL SCHOOLS. MATTER: International Journal of Science and Technology Vol 4 No 1 (2018)

[18] Walvoord, B. (2010). Assessment clear and simple: A practical guide for institutions, departments and general education (2nd ed.). San Francisco, CA: Jossey-Bass.

[19] O'Toole, K. (2007). Assessment in experiential learning: The case of a public policy internship. Education Research and Perspectives, 34(2), 51-62

[20] Qualters, D. (2010). Bringing the outside in: Assessing experiential education. New Directions for Teaching and Learning, 124, 55- 62. doi: $10.1002 / \mathrm{tl} .421$

[21] Ferns, S., \& Zegwaard, K. (2014). Critical assessment issues in work-integrated learning. AsiaPacific Journal of Cooperative Education, 15(3), 179188.

[22] Lirola, M. M. (2018). Multimodal teaching evaluation with a portfolio in a tertiary education language classroom. Argentinian Journal of Applied Linguistics, 6(1), 25-43.

[23] Cooper, L., Orrell, J., \& Bowden, M. (2010). Work integrated learning. A guide to effective learning practice. Oxon: Routledge 